\title{
LA VISIÓN DE LA MUJER MEDIEVAL DURANTE EL REALISMO EN LA LITERATURA Y EL ARTE
}

\author{
REBECA SANMARTín BaSTIDA \\ Instituto de la Lengua Española \\ CSIC (Madrid)
}

Dentro del marco de mi investigación sobre el medievalismo de la segunda mitad del siglo $\mathrm{XIX}^{1}$, en este artículo pretendo estudiar la consideración de la mujer medieval en unos años en los que la Edad Media era ofrecida frecuentemente como un modelo social a imitar.

Si el entendimiento de la historia de la corriente medievalista no debe reducirse a una cuestión de narrar su aparición y evolución, sino de contextualizar - social, política y sexualmente - aquellos factores que han hecho y continúan modelando la disciplina tal y como la conocemos ${ }^{2}$, es necesario revisar los fundamentos del actual conocimiento de la Edad Media y abordar los prejuicios genéricos del mismo, partiendo de que muchos campos de interés responden a una serie de cambios en la sociedad, como propone el Nuevo Medievalismo. Precisamente, los Cultural Studies, corriente teórica de gran vigencia en la actualidad que estudia la conexión del texto con las clases sociales, la etnicidad y el género, consideran este último ámbito de análisis como una reveladora consecuencia del importantísimo movimiento de la mujer que se ha producido en la sociedad occidental contemporánea ${ }^{3}$.

Desde este punto de vista, me acercaré a la construcción del ideal femenino en la producción literaria de ciertos escritores, sin excluir algunos textos no canónicos accesibles desde la prensa ilustrada ${ }^{4}$. No hay que ol-

1 Se trata de mi tesis doctoral «La Edad Media y su presencia en la literatura, el arte y el pensamiento españoles entre 1860 y 1890 », leída en septiembre de 2000 en la Universidad Complutense de Madrid.

2 Cfr. Bloch y Nichols (1996: 13).

3 Véase Fuery y Mansfield (1997). Se trata de ese interés por la diferencia, lo excéntrico y la construcción de identidades paralelas al modelo dominante que ha reivindicado especialmente el Postestructuralismo, tal y como señala Serrano de Haro (2000: 21).

4 El establecimiento de un canon textual es algo que las nuevas corrientes críticas están poniendo cada vez más en entredicho. 
vidar que la cuestión del feminismo comienza a ser candente en el período que vamos a estudiar, el del Realismo literario. Aunque apenas haya mujeres dedicadas por entonces al estudio del Medievo (por razones obvias de carácter cultural y educativo), éstas cuentan con una historia dentro del medievalismo a través de una presencia temática continua. Curiosamente, la concepción de la mujer decimonónica influirá en la manera de entender el Medievo, por lo que deberemos recordar las circunstancias que rodean a esta figura y el paradigma que se le imponía.

Esta relación entre la concepción de los siglos medios y la ochocentista del género femenino tiene un clarividente ejemplo en los estudios medievales franceses. En el Medievo y en el siglo XIX, un ideal de superioridad femenina oscurecía una profunda controversia cultural sobre el lugar social de la mujer. La «cuestión de la mujer» estaba en el centro del debate sobre la literatura trovadoresca y la misoginia cuando Gaston Paris definió la noción de amor cortés en $1883^{5}$. El miedo a perder el ideal de la feminidad ${ }^{6}$ tuvo sus consecuencias, de esta forma, en el ámbito de los estudios filológicos: la aceptación incuestionada de la definición de la naturaleza femenina en los estudios literarios no dejó de obstaculizar el entendimiento del rol histórico de la mujer en la Edad Media. Esto nos pone sobre aviso en torno a lo que esconden muchas de las teorías y visiones con las que se construye imaginariamente una época que, por ser lejana, resulta más fácil de manipular ${ }^{7}$.

5 Según el interesante estudio de Burns, Kay, Krueger y Solterer, si al leer la narrativa cortés como una idealización refinada de la mujer, Paris la concibió dotada de una superioridad moral y sexual sobre el caballero, su «notion of female empowerment through love represents a late-nineteenth-century ideal of femininity rather than the historical reality of women in either the twelfth or the nineteenth century» (Burns et alii, 1996: 229). De este modo, «If 'courtly love' as a concept was invented in the late nineteenth century, it was, at least in part, because the notion of a disenfranchised woman empowered by male mystification corresponded so well to the desires of modern men» (ibidem: 229-230).

6 Estas formulaciones de G. Paris coinciden con los temores de Freud por el declinar del ideal femenino en el auge de la legislación social de la mujer, temores que expresa en una carta a su novia en 1883. Freud acepta la reforma como inevitable, pero quiere mantener pese a todo aquello que considera lo más delicioso que se le ofrece al hombre en el mundo: el ideal de la feminidad. Si bien la ley debe dar a las mujeres los derechos de los que se les ha privado, su deseo es que permanezcan como han sido siempre: criaturas adoradas en su juventud y amadas en su madurez. Citan Burns et alii (1996: 255) de Sarah KofMAN, L'énigme de la femme: La femme dans les textes de Freud, París: Galilee, 1983, p. 267.

7 A partir de la noción de amor cortés establecida por Paris, no nos puede extrañar que en el Simbolismo el sexo femenino resultara ser «thoroughly and often selfconciously medieval», es decir, que la mujer sea deificada como presencia ideal, como figura de 'Beata Beatrix', princesa de sueño y dama de lis; o que, a partir también de connotaciones supuestamente medievales, sea representada como 'la Bête venimeuse et nue', la mercenaria de las Tinieblas, la sierva absoluta del Diablo en Huysmans, o ese 
Pero no solamente en Francia se fomenta un tipo de modelo femenino. En Inglaterra, donde la «pureza» alcanza su máximo grado de valoración a partir de 1850, en The Broad Stone of Honour de Digby las mujeres presentadas se parecen más a los modelos de esposas decimonónicas sacrificadas y maternales que a sus supuestos correlatos medievales (Girouard, 1981). Además, según Boos (1992), la época medieval interesará especialmente a los victorianos por ser un tiempo en el que el adulterio estaba permitido a hombres y no a mujeres, por lo que era adecuado al papel marginal que debían cumplir éstas en la sociedad contemporánea. Estamos en el momento en que se anima el modelo patriarcal de la familia inglesa, y ahí tenemos los poemas de Tennyson para comprobarlo ${ }^{8}$. Sólo Morris o Engels se muestran algo preocupados por el papel de la figura femenina del Medievo, y pintan a damas infelices o trágicamente frustradas, reflejando así indirectamente el descontento y la subordinación de la mujer victoriana ${ }^{9}$. Pero no ayudaron a su empresa las más importantes escritoras decimonónicas inglesas, que apenas buscaron el mundo medieval como trasfondo, quizás porque lo veían demasiado oscuro ${ }^{10}$.

En cuanto a España, la situación es bastante similar: durante largo tiempo, la mujer medieval representada responderá al imaginario social dominante. Bretz (1992) habla de una silenciosa ansiedad en los textos en torno al tema de la liberación de la mujer: mientras unos pocos se expresan

ser tan «ingenuamente inmoral», juguete favorito de un primordial Démon en Gourmont (Dakyns, 1973: 253).

8 Tennyson, en sus Idylls of the King, muestra que las mujeres artúricas debían inspirar a los caballeros para realizar nobles hechos de acuerdo con los dictados del rey. Como dice Cohram (1992: 81), «In order to do so, the female figures must comply with the Victorian prototype of the perfect woman, who is sexually pure and is both a submissive wife and seflless mother». El propósito de Tennyson en estos versos es subrayar la importancia del papel de la mujer para que el hombre cumpla con el suyo. «The creation of a hierarchy of women who are assessed according to the values of Tennyson's audience reveals the extent to which the poet transformed the medieval legend to suit Victorian sensibilities. (...) The presentation of marriage and the importance of domestic harmony in the Idylls demonstrate that Arthur's ability to create and sustain an ideal realm depends directly upon the morality, especially the sexual conduct, of the female characters» (ibidem: 105). El papel de la mujer es así el de ser guardiana e inspiradora de la virtud.

9 Boos destaca la importancia de estas excepciones. «Alternatives to the dreary typology of Tennyson's Idylls of the King, with its submissively wifely Enid, conniving harlot Vivien, and destructively adulterous Guenevere, included Arnolt's Iseult of Cornwall, Rossetti's Rose Mary, the suddenly-awakened Guenevere of Morris's early 'Defence', the indomitable Gudrun of his Earthly Paradise, and Swinburne's tragically noble Iseult in Tristam of Lyonesse» (Boos, 1992: 10).

10 Si Christina Rossetti, la hermana más joven del traductor de Vita Nuova, usó generalmente una ambientación legendaria, los settings de sus poemas carecían de especificidad. Además, la sátira más divertida y salvaje del medievalismo poético en su peor aspecto provino de E. Barret Browning. 
con contundencia, la mayoría lo hacen con menos claridad, sin duda bajo el peso de variados prejuicios ${ }^{11}$. No obstante, como veremos, el movimiento realista conllevó una reevaluación de la figura femenina en los siglos medios, que modificó la tradicional consideración romántica (que no dejará, pese a ello, de estar presente) y diferirá también de la modernista.

Un ejemplo de la visión conservadora que hereda la segunda mitad del XIX del Romanticismo es la que nos muestran Peset, Garma y Pérez Garzón (1978: 131-136) en el fragmento que reproducen de la obra de divulgación de Antonio Pirala El libro de oro de las niñas, cuya primera edición parece ser de 1849-1850, pero que en 1889 iba ya por la trigésimosegunda. El capítulo dedicado a la historia de la mujer muestra una idealización de su estado en el Medievo, presentándolo como algo deseable. En la defensa de la dama de entonces, se dice, perdían la vida los caballeros o la arriesgaban en torneos para obtener solamente una banda, una flor o una fútil pertenencia de su amada. «Llevábase hasta el exceso el cariño a la mujer, que era causa de las mayores virtudes y heroísmo» (cit. en ibidem: 135). Habla el pasaje de las muchas «heroínas» que tenía entonces España, aunque sus «delicadas» manos no estuvieran hechas para manejar la espada ni tuvieran corazón para el odio ni la enemistad. Este tipo de comentarios se repetirán en los textos de nuestra época que ofrecen la época medieval como un modelo de vida envidiable para la mujer. De esta forma, bajo la excusa de destacar la importancia de su rol, se seguirá encerrando a ésta dentro de unos moldes cerrados.

Esta actitud la encontraremos también en textos medievalistas de intelectuales liberales como Valera. Éste, en El cautivo de doña Mencía, recuerda un estudio de Rosa Cleveland que «procura demostrar que la capital misión de la mujer es la de revelar al hombre sus altos destinos, alentarle en la lucha e inspirarle el brío y la confianza que son menester para al-

11 Si el movimiento krausista estuvo activamente envuelto en la corriente antiesclavista y la reevaluación del papel de la mujer, trabajando activamente para incrementar su acceso a la educación durante los años 60 y 70, encontrará variadas y múltiples resistencias. En el lado conservador, la palabra familia era parte de un sociolecto ideológico que connotaba oposición al amor libre, a la emancipación de la mujer, a la legalización del divorcio y a cualquier cambio en los roles tradicionales. Las mujeres envueltas en los actos violentos de los tempranos 70 prometían el amor libre, como los cantonalistas; conservadores y neocatólicos asociarán entonces durante largo tiempo la emancipación de la mujer con la actividad revolucionaria y en particular con la cultura francesa. En los años siguientes a la República, los comentarios liberales sobre las mujeres serán cada vez más desaprobadores de sus libertades. Sin duda, el recelo a la pérdida de un control secular provocaba esa hostilidad latente en el crítico masculino hacia las escritoras. La tesis del determinismo biologista será incluso utilizada para defender la inferioridad de la mujer, como veremos. Y esto influirá también en la recepción de los movimientos literarios; para Bretz, hay una desconfianza hacia el feminismo en las discusiones sobre el movimiento naturalista, en las que Pardo Bazán juega un gran papel. 
canzarlos» (Valera, 1908: 134) ${ }^{12}$. Es decir, el mismo paradigma que ofrecía Tennyson en sus poemas: la mujer es la que señala al hombre sus altos designios, por lo que, si incumple su papel, el reino o el paraíso se viene abajo. Al tiempo, la figura femenina debe mantenerse siempre en un discreto segundo plano, como hace doña Mencía, para estimular y no obstaculizar las hazañas heroicas masculinas ${ }^{13}$.

También en la interpretación de la historia nos topamos con los mismos patrones. Si Gichot (1878), en su libro sobre don Pedro, asegura que doña Blanca tenía que haber aceptado como dama discreta la voluntad de su marido, en lugar de rebelarse contra su encierro en Toledo y levantar discordias ${ }^{14}$, Ferrer del Río (1851) opina que María Padilla debería haberse ido a un claustro cuando se casó don Pedro. No se le permite así a la mujer la posibilidad de la libertad, a través de unos prejuicios contemporáneos que se extienden sin pausa hacia el Medievo. La mujer que se prefiere entonces no es la Urraca emprendedora, ni la «de armas tomar», como María la Brava -excepción hecha de algunas heroínas de Valera o de Pardo Bazán, aunque ambos caigan en contradicciones-, sino la sacrificada María

12 Este delicioso relato de Valera (1908: 101-134), de 1897, sitúa su historia hacia el año 1470. Como en Pepita Jiménez, nos encontramos con el tema de la mujer viuda y madura - de 37 años-, de carácter fuerte y emprendedor, que se enamora, perdiendo los papeles. Su enamorado es un muchacho joven, de veinte años menos, llamado Gonzalo Fernández de Córdoba, «rapaz» atrevido a quien doña Mencía llama «niño» (ibidem: 110). Aunque en principio la relación sexual entre doña Mencía (que lucha entre su austeridad de veinte años y un juvenil sentimiento de amor) y Gonzalo permanece en términos ambiguos, luego se da por sobreentendida. Ella, finalmente, se recluye en un convento y le escribe una carta apasionada y bellísima, donde recordamos el tono de los parlamentos de Pepita, sincero y atrevido, con la diferencia de que se intenta utilizar aquí un cierto lenguaje arcaico, algo novedoso en Valera. Doña Mencía, con la fatalidad del personaje de Dido, no se arrepiente de lo que ha hecho, está orgullosa de su amor y de lo que ha vivido. Lo que más destacaríamos de este cuento es esa sugerente pintura psicológica de sus personajes; en cuanto al ambiente medieval, es un simple telón de fondo: a Valera no le interesaban las costumbres y las tradiciones del Medievo, sino la oportunidad, en este caso, de plantear una historia interesante. Nos encontramos ya muy lejos de Scott.

13 El discurso de Saavedra ante la RAE de 1863 es otro ejemplo de esta idealización de la vida medieval; allí habla de una literatura «donde se reflejaban la lealtad caballeresca, la fantasía mística, el heroísmo ideal, el amor respetuoso a la mujer rehabilitada» (RAE, 1865, III: 459).

14 Gichot piensa que don Pedro hubiera realizado la unión de Castilla y Aragón si le hubieran dejado sus enemigos, entre los que se encuentra su mujer, que no se portó discretamente al rebelarse contra su marido. Gichot ve en la muerte de don Fadrique y el comportamiento del rey con doña Blanca un acto de tremenda justicia; incluso le parece un proceder generoso el hecho de limitar el castigo de una esposa infiel a una separación de por vida (Gichot, 1878: 97), pues, en su opinión, sí hubo relación adúltera. Si en otros muchos relatos, Blanca de Borbón era la mujer víctima, flor de un día (se la suele apelar floralmente) muerta cruelmente por la maldad de su marido, para Gichot es aquí la dama que reúne a la gente contra su marido en vez de someterse a él. 
Coronel, quien, según la leyenda tradicional, quema su cara, cual nueva Lucrecia, para salvar su honor. La pasividad y el conformismo son virtudes en la mujer: generalmente, se escoge como protagonista de los relatos de ambientación medieval a la doncella sumisa, leal, fiel a las rutinas domésticas. Y, cuando no es así, se la critica: por ejemplo, a la reina Sibila Forcia, que es tachada de excesivamente ambiciosa ${ }^{15}$.

Un paradigma constantemente esgrimido, no obstante, es el de la reina Isabel la Católica, presentada como modelo de perfecciones ${ }^{16}$. Se intenta entonces establecer un vínculo de unión entre ésta e Isabel II, partiendo de obras como la de José Guell y Renté, de 1858, Paralelo entre las reinas católicas doña Isabel I y doña Isabel II. Comparación que vemos también expresada en el Romancero de la guerra de África y que será especialmente recurrente durante la guerra carlista, cuando los liberales mitifiquen el papel de la mujer al frente de la monarquía para avalar la sucesión de Isabel II frente à don Carlos. Desde este punto de partida, sí se acepta el carácter emprendedor en la mujer.

En la misma línea, en cuanto a los personajes históricos extranjeros, Juana de Arco será el más abordado en los relatos de nuestra época. Junto a María Estuardo, se perfila como una de las mujeres de la historia de moda en estas décadas ${ }^{17} \mathrm{y}$ en el país vecino, al igual que Roldán, va a recibir aclamación tanto por parte de partidarios de monárquicos como de republicanos, quienes durante el Segundo Imperio intentan ponerla de su parte (Dakyns, 1973). En nuestro país, Pilar Sinués de Marco no dejará de echar mano de la leyenda de esta «virgen mártir» para proponerla como modelo al segmento femenino decimonónico ${ }^{18}$.

15 Manuel FERnÁNDEZ y GonZÁleZ, «La Reina Sibila. (Crónicas de Aragón.- Reinado de D. Pedro IV)», La Ilustración Española y Americana (1880), XXXVIII (15 de octubre), pp. 227-230; XXXIX (22 de octubre), pp. 243-246.

${ }_{16}$ Para el pensamiento moderado, al que pertenece Bécquer, la época de los Reyes Católicos «constituye el momento ideal de la sociedad española en que coinciden la unidad religiosa con la territorial y política. El cardenal Cisneros e Isabel I representan la alianza entre el cielo y la tierra» (Benítez, 1971: 36).

17 La vida de la heroína se relata repetidamente en una revista como Parte Literaria Ilustrada de El Correo de Ultramar, que, por ser compuesta en París, recoge sobre todo los acontecimientos franceses, pues sin duda había en estas narraciones una intención nacionalista implícita. Sobre la santa se compusieron además dos óperas: la Juana de Arco escrita por Barbier y con música de Gounod, que tuvo muchísimo éxito, y la de Mermet, algo menos lograda.

18 Pilar Sinués de Marco, autora de El ángel del hogar, de 1859, y de biografías de mujeres medievales, escribe sobre Juana de Arco un relato muy convencional y moralista - con la santa nada menos que enamorada del rey francés- en la Parte Literaria Ilustrada de El Correo de Ultramar de 1861 (números 434-441). En sus Glorias de la mujer, realiza también una novela histórica sobre Isabel I, de 1878. Pilar Sinués es ejemplo de un modelo estético, «la tendencia docente isabelina, cuya legitimidad constitucional termina con el triunfo de la Revolución Gloriosa en 1868 y la consolidación de la novela realista en la década de 1870» (Sánchez Llama, 1999: 272). 
La mujer del Medievo representada en este tipo de textos se mueve principalmente por amor y, cuando es «malvada», los motivos radican en la necesidad de este sentimiento, más que en la ambición ${ }^{19}$. El liberal Castelar muestra varios ejemplos de esta concepción tendenciosa del sexo femenino. En su crítica al Pedro Abelardo de Ferrari, vemos cómo la mujer se define exclusivamente por su rol amoroso ${ }^{20}$, y en la segunda parte de El suspiro del moro, que publica en 1886, la fuerza de la pasión en la mujer se hace manifiesta cuando, pese a las convicciones religiosas férreas que la de Solís ha mostrado en el pasado, acabe cayendo bajo el yugo del sultán. "Quédense la conquista de reinos y mundos para la fuerza de los hombres; a nosotras debe bastarnos la conquista de reducido dominio, la conquista de un solo corazón», dirá Isabel (Castelar, 1886, II: 159). Así pues, amar es el principal oficio de la mujer (parafraseando a San Juan de la Cruz): «La mujer vive para el amor, y en cualquier ocasión de la vida que se le ofrezca y presente, si no lo corresponde y lo paga, lo considera y lo examina» (ibidem: 43). Y su valoración personal le viene de su capacidad de despertar amor: cuando Zoraya es requerida de amores por un gallardo infiel, aunque esto no cautiva necesariamente su corazón, sí al menos su amor propio.

Por estar destinada a amar, la existencia de la mujer en este imaginario (medieval y decimonónico, pues el uno remite al otro) consistirá en esperar la aparición del hombre que la haga feliz, como la Bella Durmiente aguarda al caballero que la despierte. Se trata de la imagen de la mujer pasiva, muy explícita en la protagonista de Fra Filippo Lippi ${ }^{21}$.

Otro papel fundamental que cumple es el religioso. La protagonista de El suspiro del moro explica al embajador Vera que la misión de la mujer es rezar mientras el hombre lucha: para ella, las tierras fronterizas debe-

19 Así, en una novela de Fernández y González (1958: 50), doña Lambra se muestra orgullosa y feliz de haber conquistado a Gonzalo «Gustios» con su «amor satánico» porque «apagaba su sed de amor devorándolo a raudales». Y en La peña de los enamorados, relato del mismo autor, nos encontramos con que «A Aixarah no la detenía su amor al padre./ Una mujer enamorada no tiene más padre, más madre, ni aún más Dios que su amor» [La Ilustración Artística, 60 (19 de febrero de 1883), pp. 59 y 62-63: 63]. También en el drama Venganza catalana, María, aunque griega, se siente española porque: «La patria de la mujer/ Es el amor del marido» (García Gutiérrez, 1866: 566).

20 «En los acentos de la mártir Eloísa óyense los primeros latidos del corazón de la mujer en la Edad Media, reivindicando, frente a todas las tiranías, su exclusiva y propia finalidad, el amor, como en los esfuerzos de Abelardo para dar al dogma los comentarios de la razón se ve a la idea reclamando la primera entre todas sus facultades, la libertad» (Ferrari, 1910: 247). En esta comparación entre los objetivos del hombre y de la mujer medievales, huelgan los comentarios.

21 «Lucrecia seguía la ley de su sexo; aguardaba pasivamente a que la casualidad o la providencia le presentasen el deseado ser, a quien debiera amar con toda su alma, y por quien acababa de sacrificarse fantásticamente, sin estar segura de su correspondencia» (Castelar, 1879, I: 222). 
rían estar llenas de campamentos donde los hombres trabajen en guerreros ejercicios y las mujeres oren en monasterios ${ }^{22}$. De hecho, cuando Isabel de Solís abandona su fe, es decir, su función como mujer, le sobrevienen todas las desgracias.

También la obediencia está en el orden de las exigencias. En la misma obra, el padre de Isabel (que tiene una arriesgada concepción del honor, hasta el punto de querer sacrificar a su hija por él ${ }^{23}$ ), le dice a ésta que no debe «tener ni más pensamiento, ni más conciencia, ni más voluntad, que el pensamiento y la conciencia y la voluntad de tu padre» (Castelar, 1885, I: 108). Adelantando una reflexión casi simbolista, Isabel sostendrá entonces que el alma de la mujer, "cuando reza en el templo santo, se parece a los ángeles que rodean las pinturas místicas y que nadan en los vidrios de colores colocados en los rosetones y en las ojivas de nuestras iglesias» (ibidem: 111-112).

Por supuesto, los escritores románticos que siguieron escribiendo en el último tercio de siglo, como Zorrilla ${ }^{24}$, ofrecen reiterativos ejemplos de esta concepción del sexo femenino. En La leyenda del Cid, de $1882^{25}$, Jimena

\footnotetext{
22 «A Dios rogando y con el mazo dando, enseña el refrán castellano en su natural y sencilla filosofía. Pues bien, los varones deben dar con el mazo aquí de continuo para tenerlo ejercitado y apercibido, mientras las hembras debemos vivir en oración perpetua para tener a Dios importunado y vencido, a fin de que nos acorra en tanto y tanto trance como a cada paso nos aflige y en los cuales hemos menester su divina misericordia» (Castelar 1885, I: 54).

${ }_{23}$ Por miedo a que su hija caiga en el harén, sabemos que Solís se decide a matarla, para que no se cumplan los presagios en torno a ella, pues «la virgen castellana, que lleva sangre del Cid en las venas, timbres de cruzados heroicos en el escudo, apellidos inmortales entre sus nombres; nacida para dar hijos, continuadores de la cruzada española en el hogar $u$ oraciones propicias al cielo en el templo, va bien pronto a verse (...) manchada por los tigres del desierto, convirtiéndose de ángel celestial en triste impura manceba» (Castelar, 1885, I: 131-132). Habrá que esperar a los poemas premodernistas para que a la mujer se la reconozca al menos el derecho de gozar, aunque no deje de ser en ocasiones una Beata Beatrix.

24 También para el vallisoletano la mujer ha nacido para el amor, como asegura en su leyenda La Pasionaria (Zorrilla, 1859: 267). Por otra parte, el sexismo y las circunstancias autobiográficas (conocido es el hecho de que Zorrilla tuvo muchos problemas en su matrimonio) se notan cuando habla del tratamiento del pasado en la poesía. En El castillo de Waifro, de 1868, explica así la fascinación de los hombres de su época por lo pretérito: «Lo pasado es la querida/ Ausente, embelesadora, (...)/ Lo presente, por desdicha,/ Es como la mujer propia,/ Que anubla su poesía/ Con las miserias corpóreas» (Zorrilla, 1894: 19).

25 En La leyenda del Cid, a pesar de los reconocibles clichés, Zorrilla introduce una nota diferente de la habitual en sus versos, en la línea de parnasianos como Lisle y sus poemas bárbaros, con una Edad Media más cruda, que también encontramos en Hugo y La Légende des Siècles. Zorrilla hará en este sentido una concesión al pensamiento de la época, bajo la influencia del aire progresista del positivismo. El poeta nos recuerda que en aquella edad bravía existía en las cortes y las aldeas un enorme retraso (Zorrilla, 1882: 365 ), y, desde un no acostumbrado prisma realista, nos describe la vida cotidiana
} 
es presentada como una joven discreta, cualidad que es aplaudida porque sabe dónde está su sitio - si el Cid calla, en cambio, es porque un hombre bravo no debe mostrar «lengua brava»- ${ }^{26}$. La ingenua Jimena basa entonces su vida en esperar la vuelta de su marido (de batallas o correrías) para ser feliz. Se trata de un ideal de familia castellana en la que el hombre, una vez más, lleva las riendas. Rodrigo conmina a todos a obedecer a su padre pues «Dios manda en el universo/ y nuestro padre en su casa» (Zorrilla, 1882: 44) ${ }^{27}$.

Para contraponerla al ideal cristiano, la figura femenina de Oriente, la musulmana, es ligada a un comportamiento violento o sensual, imagen en la que pudo influir el texto de Las Mil y una noches ${ }^{28}$. Castelar, en Fra Filippo Lippi, nos expresa muy bien las razones de esta caracterización a través de Sobeiya, la hija del Sultán de Túnez que se rinde ante Filippo y a quien según el autor no se le puede exigir «rigidez moral» ${ }^{29}$. Bajo la apariencia de un moderado feminismo', Castelar reclama entonces la libertad de la mujer cuando compara la situación de la musulmana con el privilegiado papel que tenía la figura femenina en la religión cristiana, a tra-

y las costumbres de los hidalgos de entonces. Zorrilla publica este poema en 1882, por lo que no nos debe extrañar ese mayor distanciamiento a la hora de enfrentarse al Medievo, que también se da en muchos autores del momento y que aumentará con el Premodernismo.

26 «Trataba el rey con Jimena/ de trabar plática en vano,/ porque ella su discreción/ acreditaba callando;/ pues sabe que la mujer/ que habla con un soberano,/ es pez que abre mucha boca/ en agua en que están pescando» (Zorrilla, 1882: 131). Rodrigo mata al padre de Jimena, pero le acabará dando otro hombre a cambio, él mismo, gesto que aplaude todo el pueblo (ibidem: 124-125).

27 La cabeza del hogar se demostrará por la fuerza bruta: será el Cid el que tome el mando, aunque sea el hermano más pequeño, pues los otros no muestran tener su grado de virilidad.

${ }_{28}$ Las jóvenes moras, ataviadas con ajorcas y borceguíes, se muestran siempre plenas de exotismo, aunque, especialmente en los poemas, son casi igual de puras que las cristianas que suspiran ocultas tras velos pudorosos. Todavía no hemos llegado a la mujer modernista conscientemente fatal, sin credo de castidad. Como las mujeres cristianas, las árabes de las leyendas de Simonet no les van a la zaga en santidad, si exceptuamos a Medina Zahara. Algunas descripciones de estas vírgenes son un ejemplo de la delectación sensual que pueden llegar a alcanzar los escritores, con recursos como la comparación de la mujer con una flor, metáfora sacada de la poesía oriental, que en estas décadas se empieza a descubrir.

${ }_{29} \mathrm{Su}$ entrega al italiano como un cuerpo inerte arrastrado por la pasión (en las palabras del autor) se considera normal porque estaba colocada en un ambiente apestado (obsérvese la connotación pasiva que denota todo el vocabulario) y por ello resultaba sencillo que se entregara a un abrazo. «Una pobre muchacha como Sobeiya (...) educada en el serrallo, persuadida de que en otro mundo encontrará sensuales placeres, sujeta a la fatalidad como a una cadena de peso incontrastable, debe rendirse al asalto de las pasiones y encontrarse de sus pasiones verdaderamente esclava por faltarle aquella primera libertad del alma» (Castelar, 1879, III: 169). 
vés de las impresiones de cautiverio de Isabel de Solís ${ }^{30}$. Una trampa más, pues una nueva esclavitud será ese papel tan extendido en la literatura de la época de ángel del hogar ${ }^{31}$.

Así, hay que decir que la gran preocupación que se da entonces por la situación de la mujer en el harén ${ }^{32}$, además de responder a causas morbosas y a un nuevo espíritu humanitario, parece obedecer a una manera deliberada de desviar la atención de la difícil situación coetánea de la mujer, cuando se empezaban a reclamar con fuerza sus derechos. Como al lado de sus compañeras de sexo orientales la dama medieval-contemporánea salía mejor parada y disfrutaba de un rol algo más activo, se le impone a ésta el conformarse con su suerte. De todas formas, no podemos olvidar su encuadramiento dentro del movimiento orientalista que surge con fuerza en el último tercio de siglo, descrito por Litvak (1985) en un magnífico estudio.

Así, la situación de la mujer en el harén, tan presente en los grabados de la prensa ilustrada ${ }^{33}$, interesará a aquellos arabistas que, como Simonet,

30 «La mujer cristiana pudo comparar en aquel momento, cuando el destino la ceñía y ligaba con lazos de flores a un serrallo donde su virginidad y su pureza se habían salvado por el desdén de sus señores, pudo comparar la madre de familia, la esposa única, la compañera de todo el ser y de todo el existir, la intercesora entre la tierra y el cielo, numen de la poesía, ornato de la sociedad, estrella de la vida, gala de los torneos, diosa del hogar, con aquellas pobres mujeres enjauladas como las aves de las pajareras y reducidas a viles instrumentos del placer como cualquier objeto placentero y voluptuoso, como los pebeteros de mirra, como los pomos de aroma, como las guzlas de sonantes cuerdas, como las cosas voluptuosísimas y viles» (Castelar, 1886, II: 355-356).

31 Esta comparación de la situación de la mujer cristiana con la oriental la encontramos también en el Granada, poema oriental de Zorrilla (1852: 54) cuando habla de Isabel la Católica: «iSu aposento real cuán diferente,/ Cuán distinto su púdico reposo/ Del sueño de las reinas del Oriente,/ Inquieto en camarín voluptuoso!/ De torpe desnudez el aliciente/ Atrae allí no más al torpe esposo,/ Y sobre el cieno del placer reposa/ Sólo el cariño de la infiel esposa».

32 El harén del moro se toma casi siempre como un rasgo imprescindible en su presentación en los poemas de la época, lo que da lugar al motivo recurrente de la favorita del harén. Motivo que no sólo se repite en la literatura sino también en el arte. Recurrente es la figura del moro que dice amar mejor que el cristiano y que ofrece gran lujo a sus mujeres, de las que quiere ser señor. En los poemas orientales suele haber una pícara incitación al placer por parte del moro a la cristiana, que es requerida para que ame a su hombre como mora, es decir, por las descripciones previas que se nos dan, para que sea sumisa, quiera ser admirada por su dueño y arda en sus ojos la pasión.

${ }_{33}$ La representación del harén será una constante de los grabados de esta época, relacionada estrechamente con el exotismo finisecular (Litvak, 1979) y el interés por las costumbres moras que se venían reflejando en artistas como Fortuny y en el previo Romanticismo. Muchas de estas escenas de serrallo se ambientarán en palacios moriscos de la España medieval. Así, el cuadro de Francisco Beda donde se representa la recepción de la favorita en la corte de Abderramán III en La Alhambra (reproducido en La Ilustración Artística de 1887), o el de M. Benjamin Constant, que muestra al rey de Granada observando su tesoro de «mártires» cristianas medio desnudas dispuestas para 
resaltarán el estado ventajoso de la mujer cristiana medieval frente a la árabe ${ }^{34}$. Argumentos como el de Pedro de Madrazo, en su introducción a las leyendas de Simonet, se repiten constantemente. Madrazo (1858: xiv) establece una distinción entre la empalagosa galantería de los árabes, nacida de un sensualismo egoísta, y el respeto y el amor a la mujer que se da entre los cristianos, y señala que «la condición de mercancía empieza para la mujer con la misma infancia» en el Islam (ibidem: xii); argumento que, junto con otros, le sirve para demostrar la magnífica situación actual y medieval de las mujeres cristianas. Esta supuesta concepción privilegiada tiene su correspondiente correlato en la visión de la literatura medieval, por ejemplo en el origen de la novela que establece Blasco Ibáñez ${ }^{35}$.

ser objeto de su placer y para disputarse sin desearlo el puesto de la favorita, en «Nuestros grabados./ Después de una victoria (Alhambra)», La Ilustración Ibérica, 21 (26 de mayo de 1883), pp. 6-7. También la sensualidad del cuadro de Richter, Un harem en Granada, llama poderosamente la atención, en Ed. RICHTER, «Un harem en Granada», La Ilustración Ibérica, 160 (23 de enero de 1886), pp. 56-57. Para el comentarista, las mujeres no podían estar mejor «instaladas» en otro sitio que en Granada (véase la página 62 del mismo número). Por otro lado, Pradilla pintará varios cuadros sobre el mismo tema, rebosantes de erotismo y sensualidad —en la línea del romántico Ingres-, aunque no enmarcados en el pasado medieval: dos de estos cuadros de Odalisca, de 1877, aparecen reproducidos en Rincón García (1987: 102). En muchos de estas imágenes se nos presenta a las odaliscas aburridas: el tema del ocio de la mujer en el harén era un motivo de «preocupación» para los artistas europeos.

${ }^{34}$ Cfr. Manzanares de Cirre (1971: 156-158). En 1891 Simonet leyó una memoria en el IX Congreso Internacional de Orientalistas, celebrado en Londres, sobre el tema «La mujer arábigo española». En esta conferencia aborda su tesis de siempre: los logros de los árabes en el campo cultural son debidos a los españoles. Si las mujeres alcanzaron entre los mahometanos más libertad que la usual entre los orientales y brillaron por su ingenio e ilustración, esta condición privilegiada del bello sexo no fue inspirada por el Islam, ya que la ley alcoránica oprime y degrada a la mujer, sino por la presencia poderosa del elemento cristiano. A la tradición hispano-cristiana pertenece el rendimiento amoroso lleno de "abnegación y pureza» que hay en los poetas españoles árabes, y no en otros musulmanes, más groseramente sensuales. Y es que, según Simonet, se debe al Evangelio la emancipación y el ennoblecimiento de la mujer. Véase F. J. SIMONET, Memoria presentada al IX congreso internacional de orientalistas celebrado en Londres en sept. de 1891, Granada, s. a.

35 En el Discurso de Don Vicente Blasco Ibáñez sobre "La primera de las novelas» (Blasco Ibáñez, 1987, IV: 1343-1347), el valenciano, ya en 1920, relega a la mujer al ámbito de la esfera privada y señala la supuesta contribución de la Edad Media a la situación de la mujer, pero sin dejar de limitarla a unas posibilidades reducidas. A través de esta concepción justificará su teoría sobre el origen de la novela: en el mundo antiguo era imposible la literatura novelesca porque la novela es epopeya del hogar y en las sociedades antiguas todo se basaba en la vida pública y no había por tanto lugar para los relatos de vidas privadas. La novela es de este modo imposible sin la mujer, y ésta en el mundo antiguo tenía un papel muy secundario. «Fueron precisos el cristianismo y la vida particularista y fragmentaria de la Edad Media para que el hogar y la mujer adquiriesen la importancia que hace de ellos los principales elementos de la novela moderna» (ibidem: 1345). 
Ahora bien, si durante el Romanticismo se sobrevalora el universo trovadoresco y su idealización de la mujer, con la llegada del Realismo se comenzará a rechazar la producción poética cortesana, que se considera llena de hipocresía. Descubrimos curiosamente a través de Valera que una de las razones del escaso aprecio hacia estas composiciones es la idolatría de la mujer que denotan. «Del amor espiritual consagrado a la mujer han hecho grandes encomios los modernos apologistas, sin notar que el consagrarle a la mujer es una depravación y una idolatría. La única excusa que tiene este elegante fetichismo, es dar por supuesto que se adora a la mujer como un símbolo o como una imagen», dice en 1859 Valera (1913: 123124) ${ }^{36}$. Sin duda, el escritor, bajo los prejuicios de su escuela, considera que lo propio de la poesía castellana es el realismo, lejano para él del amaneramiento de estos versos, que califica de pesada y tupida vestidura «que se puso al amor contrahecho, para encubrir sus fealdades con postizos y adornos» (Valera, 1905, II:' 326). Recordemos el mito del castellano rudo, sobrio y realista, que nacerá por esta época. La poesía trovadoresca, por contrariar este mito, se considera una exportación o una consecuencia del estado de decadencia social del Bajo Medievo, como vemos en Menéndez Pelayo ${ }^{37}$.

Así, a medida que avance el siglo, aunque no dejan de estar presentes los patrones heredados, en la obra medieval se buscarán otras cosas, de acuerdo con la nueva atención historiográfica hacia la marginalidad. La creciente preocupación por el tema de la mujer se extiende a los tiempos

36 «En Laura adoró Petrarca a lo bello ideal, y Dante en Beatriz a la ciencia divina; lo cual no impidió que ambos tuviesen otros mil amores al uso gentílico y profano», continúa diciendo Valera, con talante desmitificador. En otro momento, el novelista critica la misma idolatría: «El amor místico a la mujer no respeta nada» (Valera, 1905, II: 38). Más simpáticas le resultan las esposas del Cid y García del Castañar, a las que sus maridos no aman místicamente ni de la manera escolástica, alambicada y mezclada de honor de Calderón (ibidem: 40). Valera (1910: 292-295) considera el amor místico de la mujer como un enredo engañoso, que es debido o a una malsana hipocresía o a algo que propende a lo vicioso. Dante o Petrarca son idólatras y andan sobrados de adoración si Beatriz y Laura son mujeres de carne y hueso y no figuras alegóricas de la virtud, la ciencia, la patria o la teología, es decir, de algo sublime y cercano a Dios.

37 «No es menos de reparar en nuestros Cantares de gesta la total ausencia de aquel espíritu de galantería que tan neciamente se ha creído característico de los tiempos medios, cuando a lo sumo pudo serlo de su extrema decadencia. No sólo se buscaría en balde en nuestra viril y austera poesía la aberración sacrílega o hipócrita del culto místico de la mujer, ni menos la expresión de afectos ilícitos de que no está inmune la lírica de los provenzales, sino que jamás la ternura doméstica (...) se confunde ni remotamente con lo que pudiéramos llamar el amor novelesco, que más que un afecto sano y profundo, suele ser una exaltación imaginativa. Tales estados nerviosos, tales cavilaciones y desequilibrios, son producto de una civilización muelle y refinada, e incompatibles de todo punto con el ambiente de los tiempos heroicos» (Menéndez Pelayo, 1944, I: 126). 
pasados, a la historia y a su herencia en la actualidad. Giner de los Ríos, comentando una edición del alemán Knust de los Castigos e dotrinas que un sabio daua a sus hijas, considera que este texto es útil para el estudio de la condición de la mujer en el siglo XVI y advierte, novedosamente, el legado negativo que le dejó la Edad Media ${ }^{38}$. Siguiendo, pues, los postulados de Taine, se intentará conocer ahora la vida de una época a través de sus legados literarios. Comienza entonces un ejercicio de recapacitación seria sobre la verdadera situación de la mujer medieval. Visiones como la de Pareja Serrada, que en 1875 considera todavía a los siglos medios como el período dorado de la mujer, el de su «reinado» sobre el hombre, que la adoraba ${ }^{39}$, irán quedando ligadas a una obsoleta tradición romántica. Precisamente, este movimiento, que ya no está de moda, aparece relegado a las lecturas íntimas de camarín femenino; en la década de los 70 encontramos el modelo de mujer romántica que se pasa el día leyendo novelas medievales en la cama y soñando con raptos y desafíos ${ }^{40}$, es decir, una especie de Emma Bovary española, mujer que trata de imitar ese paradigma de dama medieval fijado en los textos románticos. Es más, a través de estudios como el de Jiménez Morales (1997) en Málaga, podemos decir que la novela histórica o el drama de época fueron los géneros preferidos entre el sector femenino ${ }^{41}$. No obstante, ya hacia los 80 vemos que la mujer comienza a combinar lecturas más diversas, que la hacen conocer un modelo diferente. J. Valer de Tornón nos pinta así a su protagonista en 1886: «Virtuditas, que meditaba el Siglo Futuro y devoraba las crónicas de

38 El doctor Knust, según Giner, «señala los datos que este libro ofrece para juzgar la habitual reclusión de las antiguas mujeres españolas; reclusión, en la cual, como en tantas otras cosas, influyó considerablemente, sin duda, la condición de la mujer musulmana. Vicio éste que hoy cuesta gran trabajo desarraigar, sobre todo, en nuestras provincias», pese a las predicaciones de la higiene y del progreso de las costumbres, en el sentido de una mayor dignidad para el sexo femenino. Y añade Giner que «Todavía en estos tiempos hay localidades, donde una dama, punto menos que se desopina, si recibe a solas la visita de un hombre» y que, por lo tanto, debe mantener la puerta abierta de la habitación donde sostenga una conversación con éste para evitar bochornosos comentarios. Por ello el articulista critica los textos que predican una vuelta a esas costumbres opresoras. «No se prestan poco a ellos [a los comentarios] los Castigos e dotrinas, respecto de aquel bon vieux temps, cuya pureza de costumbres sorprende ver todavía elogiada en libros y aún en pastorales de eminentes prelados, que debieran tener a menos ser cómplices en perpetuar las leyendas de la ignorancia». «La última publicación de la Sociedad de Bibliófilos Españoles, por el Prof. D. F. Giner», Boletín de la Institución Libre de Enseñanza, 47 (31 de enero de 1879), pp. 13-14: 14.

39 Antonio PAREJA SERRADA, «Influencia de la mujer en la regeneración social. Cartas a Concha», Ecos del Guadalevín, 50 (1875), pp. 204-206.

40 José RUIZ TORO, «El romanticismo y la romántica», Ecos de Guadalevín, 14 (8 de diciembre de 1874), pp. 114-116.

41 Jiménez Morales explica a partir de estos datos el carácter conservador del sector femenino, aunque tal vez habría que hablar más del conservadurismo de la literatura que se impone a este sector público. 
Asmodeo y Almaviva, tenía a la cabecera de la cama San Francisco de Pardo Bazán, y Teresa Raquin de Zola» ${ }^{42}$.

$Y$ es que en el último tercio del siglo, bajo la influencia del krausismo, que propicia la Asociación para la Enseñanza de la Mujer, del espíritu del 68 y de políticos como Pi y Margall, que se declara por la igualdad de los sexos, la situación va cambiando. La preocupación por la adquisición de la cultura en la mujer la encontramos en la Institución Libre de Enseñanza, que crea una asociación destinada a su educación. Abundan entonces los artículos en favor o en contra de la liberación femenina, con una postura condicionada por la ideología. En general, revistas como La Ilustración Republicana y Federal defenderán la igualación de los sexos ${ }^{43}$, mientras que otras como La Ilustración Católica se mostrarán agresivamente remisas (o, más frecuentemente, «ignorarán» el tema).

Estas circunstancias provocan una variación en la visión del universo medieval. Es decir, si en el arte o en el folclore se considera la Edad Media una etapa de grandes logros y de gran espiritualidad, el baremo retrocede cuando se tratan temas como la intolerancia o la cultura, la religión, la mujer o la educación. Por otro lado, en la literatura, frente a la mujer idealizada del Romanticismo, hermosa y llena de bondad sin par, que sabe cantar o tocar el arpa, se busca ahora una figura femenina con más carácter y capacidad de decisión e iniciativa. En los nuevos relatos la mujer deja de jugar un papel pasivo, de acuerdo con las más modernas discusiones sobre su papel en la sociedad. En La Buena Fama, Valera reconocerá la libido y la independencia de su protagonista, que además ya no pertenece a la nobleza, sino al pueblo. En este relato, en el que se pone en solfa el imaginario mítico medieval, la mujer del siglo XIII aparece desmitificada, en una correlación con el paradigma femenino de la novela realista.

Justo es observar aquí, a fin de que nadie tilde a Calitea de señorita desaforada de rompe y rasga, que ella vivió hace setecientos años lo menos, en época más ruda; y sin tener dueña, ni escudero que la escoltase, como las señoritas de Madrid que llevan ahora cuando van de paseo, una acompañanta a quien llaman la carabina, Calitea por estar su madre enferma casi siempre, iba sola a sus negocios de costura, y entraba en almacenes y tiendas, y atravesaba calles, plazas y callejuelas, donde no había municipales, ni polizontes, ni alumbrado eléctrico. Era, pues, indispensable que, si quería defenderse, acudiese ella misma a la propia defensa, con algo de marcial, de arrogante y tremendo, como una Doña María la Brava. (Valera, 1907: 227).

42 J. VALER DE TORNÓN, «Virtuditas (Tipo madrileño)», La Ilustración Ibérica, 189 (14 de agosto de 1886), pp. 518-519 y 522: 519.

43 Como es natural, el feminismo tendió a rechazar el Medievo: Carolina Pérez defiende los derechos de la mujer, que es hermana del hombre y ya no puede ser «la sierva de su señor, como la consideró la Edad Media». Carolina PÉREZ, «La mujer en la democracia», La Ilustración Republicana y Federal, 10 (28 de marzo de 1872), p. 104. 
En el teatro, a medida que avance el género, se dará cabida a la innovación a través, entre otras cosas, de las protagonistas femeninas de Echegaray, que dejan de someterse tan prontamente al padre y al honor (Cabrales Arteaga, 1984: 427) ${ }^{44}$. El pensamiento liberal de Echegaray se muestra en esa enérgica condesa de La peste de Otranto que demuestra poco aprecio por su marido infiel, si bien, sin duda, el personaje más «revolucionario» será la protagonista de En el seno de la muerte. Beatriz es infiel a su marido y no parece arrepentirse de ello ${ }^{45}$; sin embargo, no se la condena, ni se la presenta como la mujer malvada de los folletines, aunque abandone a don Jaime, algo que no podríamos encontrar en el teatro del siglo XVII, con el que estas piezas suelen ser comparadas. Si en este tipo de dramas históricos el amor es una fuerza irresistible, las mujeres que aman pueden mostrarse sin escrúpulos morales, sin importarles la legalidad de su situación ${ }^{46}$. Además, llegarán a hacer gala de ideas librepensadoras, como las protagonistas del Rienzi de Acuña ${ }^{47}$. Por otro lado, también en el primer drama de Galdós, dentro de un claro manejo de tópicos, podemos hallar este original aspecto: una mujer reflexiva ${ }^{48}$.

En cuanto a las figuras de Pardo Bazán, ésta se muestra especialmente ambivalente en su biografía de San Francisco. Desde un punto de vista

44 No obstante, Revilla (1883: 120) considera que las mujeres que crea Echegaray carecen casi siempre de verdad, pero hay que advertir que en su crítica parte Revilla de presupuestos realistas.

45 Cuando García Cadena nos cuenta la acción del drama, se queja de la inmoralidad que supone que Beatriz no acabe de rechazar a Manfredo. Peregrín GARCía CADENA, «Los teatros», La Ilustración Española y Americana (1879), XV (22 de abril), pp. 271 y 274; XVI (30 de abril), p. 287.

46 Así, Cabrales Arteaga comenta cómo en la obra Pedro el bastardo de J. A. Cavestany y José Velarde, la protagonista, Aurora, señala que no se arrepiente de haber perdido el honor y la inocencia por amor.

47 Ahí tenemos la caracterización de Juana como una mujer de carácter, con un pensamiento social propio. No obstante, para Gies (1994), la historia de Rienzi pertenece realmente a la protagonista femenina, María, que se muestra siempre valiente ante el peligro. En un momento dado, María expresará con orgullo su creencia en la condición campesina de sus padres, afirmando que sus diademas en el mundo eran las canas que adornaban su cabeza (Acuña, 1990: 52). En las palabras de estas figuras femeninas, vemos a la mujer pensadora y la proyección de las opiniones de la propia autora.

48 La protagonista de Quien mal hace, bien no espere, Inés, se nos presenta en varias ocasiones como una mujer reflexiva, de pensamientos propios: en las acotaciones aparece pensativa, reflexionando, etc., o poniendo en cuestión la importancia del honor (Pérez Galdós, 1974: 267). De hecho, a sí misma se denomina «Mujer fuerte» (ibidem: 268) y en un determinado momento es capaz de llamar imbécil al nuevo rey don Fernando (ibidem: 277, v. 293). No es, pues, la figura del Romanticismo que en su inocencia y pureza no puede pensar porque sólo se mueve por amor, y que se halla siempre en inferioridad frente al varón (excepto la mujer malvada); al contrario, controla en todo momento sus decisiones y su situación y en ningún momento muestra ese amor filial que hace dudar a las heroínas románticas sobre si traicionar al amado o al padre. 
feminista, no le parece mal a la condesa la Edad Media, pues mejora la situación de su sexo: podrá ser exaltada en cortes de amor y poseer tierras y gobernar ${ }^{49}$. Puesta a alabar el Medievo, Pardo Bazán se muestra ambiguamente apreciadora de lo trovadoresco: la Edad Media otorga a la mujer gracia (mientras Roma apenas le ofrecía justicia) y la pone en los altares, como demuestra con la historia de Clotilde, en la época de los francos ${ }^{50}$. Ahora bien, reconoce que entonces la mujer no podía estudiar como ahora, por lo que se dedicaba a coser, cocinar o a la devoción ${ }^{51}$ : aborda entonces ejemplos de figuras femeninas famosas por su santidad, en una postura intermedia entre el discurso oficial y su feminismo. Sin duda, la escritora gallega quería salvarse así de la acusación de poco católica, que se debe en parte, según Bretz, a ese resentimiento que crece en un sector de la sociedad masculina a medida que Pardo Bazán y otras mujeres triunfan; por ello, éstas se verán obligadas a demostrar su ortodoxia por partida doble. De todos modos, nó deja de ser bastante novedoso que dedique un capítulo de su hagiografía a tratar la cuestión de la mujer.

Aun cuando el escalpelo agudo y las finas pinzas del anatómico y del fisiólogo disequen uno por uno los nervios, los tejidos, las fibras del cuerpo femenino, penetrando hasta los últimos grupos de células y los centros nerviosos más complicados; aunque pesando el cerebro y analizando el organis-

49 Si en la época romana, la matrona no pudo ser apreciada sino como medio de acrecentar la república, «En cambio la Edad Media coloca a la mujer sobre el pedestal del amor desinteresado, que profesa, no como vana fórmula, sino en la vida práctica: así es que en épocas de fuerza y violencia, son confiadas a flacas manos femeniles las riendas del Estado, el cetro de la justicia; se otorgan a la mujer los derechos de heredar, de administrar sus bienes, de poseer condados y feudos, de armar a sus vasallos, de juzgar los pleitos y diferencias; con la minoría del hijo empieza la regencia de la madre; las Berenguelas y Blancas de Castilla gobiernan como esforzados varones: la dama es al par sagrada y poderosa; la musa erótica se contiene y eleva, por no profanarla. Aun en la propia inmoralidad de las cortes de amor, se nota cierto espiritualismo harto diverso de la franca y brutal corrupción romana» (Pardo Bazán, 1882, I: xxvi).

so «Clotilde sirve de precursor a Carlomagno; si éste constituye la Edad Media, la Santa merovingia la anuncia» (Pardo Bazán, 1882, I: xxix).

51 La escritora señala que no estaba en la Edad Media vedada a las mujeres la instrucción: «Curioso es ver como en una edad tenida por bárbara en concepto de la mayoría, por sermibárbara en el de los más indulgentes, no se halla rastro de hostilidad al desarrollo y cultivo de la inteligencia de la mujer» (Pardo Bazán, 1882, II: 55), pero a la vez reconoce que, aunque las creaciones del entendimiento influyen poco en la mujer, frente a las del corazón, lo cierto es que ésta carecía de estímulos para dedicarse a tareas de filosofía, pues estaba alejada del aula. Para compensar, la castellana entretenía sus veladas solitarias recamando tapiz y la plebeya amasaba y cocía el negro pan. Será entonces en el terreno de la devoción religiosa donde destaque y se desarrolle más personalmente la mujer. Pardo Bazán adopta aquí un tono conservador, tal vez y siguiendo las teorías de Bretz, para hacerse eco del discurso prestigioso. Francesca es para ella el paradigma del sentimiento medieval, que rescataba «culpas grandes con expiaciones tremendas y con actos sublimes» (ibidem: 81 ). 
mo de la mujer intenten demostrar que en vaso tan frágil y quebradizo no se acomoda un alma igual a la del varón, cualquiera de los nombres que han llenado estas páginas - Clara, Rosa de Viterbo, Isabel de Hungría - es réplica elocuente a tales afirmaciones. La mujer, que conquistó con su personalidad al venir al mundo la ley del amor, mantendrá, gracias a esta ley, el derecho contra el concepto materialista que en nuestros días la amenaza con nueva esclavitud. (Pardo Bazán, 1882, II: 105).

Se trata, pues, de un feminismo muy tamizado, el único que podía pasar el control de la censura eclesiástica. La autora defiende la igualdad con el varón, pero poniendo de ejemplo a mujeres religiosas que cumplen con los requisitos exigidos a la dama decimonónica. Pardo Bazán se manifiesta a la vez contra la corriente médico-científica que vivisecciona a la mujer y que defiende en muchos casos la inferioridad de ésta en relación con el hombre.

La mujer aburrida -e insatisfecha', por tanto- aparecerá también en relatos suyos como La leyenda de la torre o La Borgoñona. En este último, publicado en $1885^{52}$, la protagonista va a buscarse la vida sola por el mundo, afrontando el aspecto del amor transgresor y de la libido (explotado más tarde por la corriente modernista), en un reconocimiento de la llamada de la carne. La Borgoñona desea al final del relato al penitente, con quien debe compartir cama, cuando está más hermoso, con sus rizados y largos cabellos y su energía sensual.

«Sí, eran los mismos ojos, sólo que antes no brillaba en ellos un fuego tan vívido y generoso (...). Sí, era la misma boca, (...) sin estos labios rojos y frescos, sin estos dientes blancos que descubría la sonrisa, sin este bigote fino que acentuaba la expresión provocativa y caballeresca del rostro. (...) la doncella iba deteniéndose con sobrada complacencia en detallar las gracias y buenas partes del mancebo. (Pardo Bazán, 1990, I: 366).

Por otro lado, a la Borgoñona, que aparece al comienzo del relato hilando en la rueca - en una imagen que nos trae a la mente el Medievo simbolista de Valle-Inclán-, en estado de aburrimiento (ibidem: 360), la toman durante gran parte de la narración por un jovencito lindo y nadie piensa que sea una doncella la que ande por despoblados, cuando «el sayal grueso ocultaba la morbidez de sus formas» (ibidem: 364). Este mundo medieval carece de idealidad, incluso de moralismo, y se nos dibuja a través de la libido del penitente y en «las blancas y mórbidas espaldas» de la protagonista, cubiertas por la madeja de pelo rubio suelto (ibidem: 364 ).

Unas palabras de Pardo Bazán en su San Francisco nos ayudan a si-

52 Según Henn (1999: 416), hacia el final de los años 80 Pardo Bazán se empezó a interesar más y más por el papel de las mujeres en la sociedad y por los temas éticos y religiosos, asuntos que están en el corazón de las novelas que escribe entre 1890 y 1896. Este cuento adelanta algunos de esos intereses. 
tuar la más sombría visión del Medievo que se establece en la segunda mitad de siglo y que se aprecia en poemas como El Vértigo de Núñez de Arce y, allende los Pirineos, en los escritores republicanos franceses ${ }^{53}$. La escritora gallega pinta aquí a un señor feudal a quien, cuando no caza ni guerrea, le consume el tedio y, solitario, ejerce el poder «de inhumana y desapiadada manera» (Pardo Bazán, 1882, I: xxiv). La escritora insiste así en que los siglos medios no fueron «edad de oro, épocas patriarcales y venturosas: importa declararlo, evitando el riesgo de embellecer y modernizar la Edad Media, y mudar y desfigurar su fisonomía histórica» (ibidem: xxiii); es decir, reclama su desidealización ${ }^{54}$.

Treinta años más tarde de estas reveladoras palabras, Pardo Bazán seguirá desmitificando el Medievo. En La leyenda de la torre (Pardo Bazán, 1990, III: 170-173), de 1912, la mujer de Payo le es infiel con un vagabundo que aparece un día por su hogar cantándole con la vihuela. Como dice el arqueólogo que comenta la historia, los nobles no vivían por entonces tan cómodamente como nos sugiere el imaginario romántico. Se plantea entonces de nuevo una más problemática y compleja visión de la mujer: vestida de la grosera lana que urdían sus siervas, reducida a escuchar cuentos de dos o tres sabidoras, con el marido ausente, la portuguesa se aburría.

Y para que los situemos en la realidad (la realidad de aquellas épocas que sólo vemos a través de la poesía) es preciso convenir en que el género de vida que en Diamonde se llevaba, y no pasiones vehementísimas, que no abundaban entonces ni ahora abundan, fue el verdadero origen del drama que dio base a la leyenda. Con afirmar esto, destruiré muchos romanticismos; pero si pudiésemos hoy reconstruir la existencia de entonces, con documentos y observaciones auténticas, veríase que el hombre y la mujer han sido iguales siempre. (Ibidem: 171).

\footnotetext{
53 Éstos, según Dakyns (1973), expresaban así su rechazo contra el gobierno de Napoleón III, que había creado toda una estética de poder en torno a lo medieval.

54 «Lejos de fingir una Edad Media al uso de nuestros días, conviene que para entenderla, retrocedamos y aprendamos a vivir con ella; arte difícil y de pocos practicado. Convengamos, pues, en que los castillos señoriales no solían ser nidos de tórtolas, sino de buitres, y que el estado permanente del feudalismo es la violencia y el combate: que el siervo se halla a merced de un arrebato de ira; que la sierva moza y hermosa, si amaneció en su cabaña, no vive segura de no anochecer en la sombría cámara del torreón; que el mercader o el viajero, al cruzar las lindes del dominio de algún señor famoso por su rapacidad, se encomienda al cielo, recordando que los que atraviesan aquel formidable territorio que se exponen a ser colgados de los pies sobre encendida hoguera, o torturados hasta que suelten oro para rescatar su sangre; que el náufrago, al arrojarlo las olas a la playa, halla, en vez de socorro, cautiverio y muerte; porque lo que el escollo produce, propiedad es del dueño del escollo. ¿Ni por qué han de sorprendernos tamaños desafueros, sabido el origen del derecho feudal?» (Pardo Bazán, 1882, I: xxiiixxiv).
} 
Se trata de la misma mirada realista que sobre esta época vierte en un determinado momento el ambivalente Gichot (1878: 242):

Conviene tener presente que en aquella Edad Media, tan poéticamente cantada y pintorescamente descrita, existían dos sociedades, la una imaginaria y la otra real, en las cuales se nos aparece la mujer bajo dos aspectos diametralmente opuestos: en la una como reina del amor y de la poesía, en la otra como instrumento de torpe placer puesto a la merced del hombre, o reducida a la condición de esclava. Allí, reina de los torneos y de las cortes de amor; aquí, viviendo en condición inferior al hombre, encerrada en la mansión feudal, sumisa en todo a su señor, obligada a sufrir sin murmurar los devaneos de su marido o los bastardos habidos por éste en otra mujer; o como en Francia, resignada a soportar sus malos tratamientos de palabra y de obra, sin otra limitación que la de que los golpes que se le dieran no fuesen con arma afilada, y que las heridas no pasasen los límites de una justa corrección.

El tema del aburrimiento tenía, además, un buen precedente en Michelet $^{55}$. Hay que destacar la aportación al feminismo medievalista de quien, por cierto, es una de las referencias preferidas en la biografía de San Francisco de Pardo Bazán ${ }^{56}$. Michelet criticará la situación de la mujer medieval en La Sorcière, todo un hito en nuestra materia, que saldrá a la luz en 1862. Mientras que historiadores republicanos menos inspirados anatemizan la Edad Media desde una prudente distancia, Michelet, dentro de su preocupación por los más desfavorecidos, hace revivir aquellos siglos en el acto de pasarles juicio y, así, la situación social femenina aparece descrita con toda suerte de detalles. La Edad Media es para él una época que causa desesperación, pues todo está previsto de antemano con una circularidad que pesa en el día a día.

Tout est prévu; on n'espère rien de ce monde. Ces choses reviendront les mêmes. L'ennui certain de demain fait bâiller dès aujourd'hui, et la perspective des jours, des années d'ennui qui suivront, pèse d'advance, dégoûte de vivre. (Michelet, 1966: 57).

55 Aunque el tema del tedio está presente en la literatura española ya en el siglo XVIII, con el tedium vitae que expresa Meléndez Valdés, y en el Romanticismo exótico a través de autores como Espronceda o Arolas, este ocio aburrido del que hablamos tiene unas connotaciones diferentes. Surge de la preocupación por la vida diaria de los siglos medios, por una nueva mirada hacia la historia. Hasta entonces, en la novela o en el cuadro romántico de tema medieval se había exaltado siempre el aspecto sublime del Medievo, en su lado trágico o heroico, y es ahora cuando, a partir de la desmitificación que supone el Realismo, va a hacer entrada este nuevo aspecto, distinto, por otra parte, de la postura decadentista con respecto al ocio.

56 Aunque la escritora gallega se refiere en su biografía únicamente a la Histoire de France, que la obra de Michelet se conoció y leyó en España nos lo demuestra el artículo de Juan Valera sobre la brujería y las ciencias ocultas publicado en 1888. Valera avisa aquí del talante anticlerical del francés. Juan VALERA, «Brujería. Ciencias ocultas (I)», La Ilustración Artística, 358 (5 de noviembre de 1888), pp. 362-363 y 366: 362. 
El francés interpreta entonces la brujería como una rebelión legítima de la mujer, que se encontraba oprimida por la Iglesia, institución que le exige una pureza total, y por una sociedad feudal que la relega al último puesto $^{57}$.

Distinto punto de vista es el que adopta Pardo Bazán (1882, II: 56-58) cuando se refiere en San Francisco de Asís a las mujeres herejes. La diferencia ideológica se percibe en que no atribuye este fenómeno femenino a la opresión social que vivía, sino a los lados «vulnerables» del pueblo y la mujer, el corazón y la fantasía (ibidem: 57), que la llevaron a caer fácilmente bajo el ensalmo de los iluministas ${ }^{58}$.

Con la llegada del Realismo, las mujeres ya no sufren locura de amor sino problemas de salud descritos con carácter naturalista, tal y como hace Coloma en su biografía de Cisneros. «No podía decirse, en rigor, que la reina doña Isabel, mujer de don Juan II, estuviese verdaderamente loca: hoy se la hubiera llamado simplemente neurasténica./ Aquejábanla manías pasajeras, tristezas profundas, obcecaciones de la mente, de que era difícil apartarla, y desfallecimientos nerviosos, que la hacían andar siempre inclinada hacia el suelo, como anciana provecta a quien llama la tierra, apoyada en una muletilla de ébano con puño de plata, de que no se apartaba ni de día ni de noche» (Coloma, 1952: 1482).

Pero el movimiento realista también dejará su impronta en el arte que vuelve sus ojos al Medievo, impronta que se plasma en una preocupación obsesiva por reflejar con minuciosidad el ambiente del pasado. A finales de siglo se introduce una visión crítica de la Reconquista y un interés por las situaciones más domésticas de la historia: lo sublime se rebaja y se introduce el aspecto social. El Naturalismo es traído entonces a los grabados de la prensa ilustrada, especialmente a la catalana de los 80 , por los pintores que posan una fría y objetiva mirada en un momento «desagrada-

57 El elogio de la pureza hizo despreciar a la verdadera mujer, ignorar sus deseos carnales. La mujer es además perseguida por su belleza, que provoca consideraciones despectivas y su representación con serpientes que salen de los cabellos. «Tous la suivent, et tous pour elle méprisent leur propre espèce» (Michelet, 1966: 103). El oficio de bruja es el único modo de escapar del círculo de la explotación: su revuelta es unirse a Satán. Frente al maltrato que sufre, comprende que de nada le sirven los santos. «¿Sontils sourds? Sont-ils trop vieux?», se lamenta (ibidem: 74). La estructura medieval, basada en la obediencia del siervo (y la mujer es la sierva del siervo), conduce a la mujer a acumular todas las esclavitudes, lo que la lleva, según el francés, a la desesperación. Por eso Michelet exclamará apasionado contra el Medievo: «On en a assez» (ibidem: 56).

58 «Fueron condenadas [algunas devotas en el XIV] como otros muchos sectarios, no por pensar, sino por errar pensando» (Pardo Bazán, 1882, II: 57). Y este error se produce porque seducían a la mujer, más que razonamientos, las acciones, el demacrado rostro del fanático, las ceremonias de iniciación en las cuevas tenebrosas, las extravagantes penitencias, las vagas teorías, el cebo de la curiosidad y el señuelo de la imaginación. 
ble» de la historia, recreándose en él de forma descarnada y sin la concesión al sentimentalismo propiamente romántico (siempre en búsqueda de héroes y de modelos a imitar), y muchas veces con una clara carga de erotismo ${ }^{59}$. Aunque no llegaron a estas publicaciones las imágenes prerrafaelistas más transgresoras, como ese sensual y perverso beso del ángel en la Saint Cecilia de Rossetti (Reid, 1975: 39-40) o su representación de la mujer caída (De Girolami Cheney, 1992), ni ese lado heterodoxo de la leyenda de Arturo que refleja Burne-Jones (con su atracción por Vivien [Miliaras, 1992]), el erotismo medievalista entró por medio de lo macabro y la representación del harén.

También en este terreno, en las revistas catalanas, encontraremos una queja continua por la situación de marginalidad y abandono que vivía la mujer en aquellos tiempos. El Realismo entrará en juego a través de esa curiosidad por las escenas cotidianas medievales, en las que pudo influir las doctrinas de Ruskin (Waters, 1992: $141^{60}$ ). Así, en la década de los 80 los comentarios a los grabados nos muestran, en su labor desmitificadora, que la vida medieval tenía su parte aburrida, que se tratará de compensar con actividades de cetrería ${ }^{61}$. Símbolo de esta nueva concepción del ennui medieval son las grandes estancias medio vacías en las que se ambientan

59 Hay grabados como el de Proceso de una hechicera en la Edad Media con un claro motivo erótico que no puede soslayarse (la mujer está desnuda y atada delante de un tribunal de hombres). Véase La Ilustración Ibérica, 4 (27 de enero de 1883), p. 1. Las imágenes sobre la dureza de la Inquisición podemos situarlas en línea con discursos como el de Echegaray en las Cortes de 1869. Por supuesto, todo esto puede ser relacionado con más facetas de la sociedad y el pensamiento decimonónico, ya sea con el placer morboso y el sensacionalismo buscado por el público en los folletines o con ese especial gusto finisecular por la crueldad y la violencia - que se hará modernista-, sobre el que escribirá Nietzsche. En cuanto al tema del tedio, además de las mencionadas raíces en el ennui romántico, que se desarrollan luego en el decadentismo, no se pueden olvidar las teorías de Schopenhauer. El dolor de la conciencia, el aburrimiento y la crueldad son asuntos que interesarán a la filosofía más moderna y que de un modo u otro están presentes en estas imágenes.

${ }_{60}$ Asistimos entonces a la visión de reproducciones de cuadros de unas señoras haciendo tapices o paseándose con azores en la mano, un caballero ciñéndose la armadura, una novia viendo las joyas de su boda, un trovador muriendo en brazos del señor feudal, un juego de ajedrez, una partida de bolos o una romería del pueblo.

${ }_{61}$ «Las damas de la Edad Media no tenían, como en la presente, un programa inagotable de fiestas y diversiones en que emplear sus eternos y monótonos días, transcurridos en el interior de un castillo, muy lleno de blasones y gloriosos recuerdos, pero más lleno aún de gentes feudalmente fastidiadas. No es de extrañar, por lo tanto, que, a trueque de interrumpir su aburrimiento, tomaran parte en expediciones cinegéticas, durante las cuales respiraban a lo menos el aire libre del campo y se sentían bañadas por un sol purísimo y desconocido en el interior de su mansión habitual. Una partida de caza era para una ilustre castellana algo como unas horas de libertad concedidas a un prisionero devorado por la nostalgia del mundo». «Nuestros grabados./ Cazadora con halcón, cuadro de F. Wagner», La Ilustración Artística, 223 (5 de abril de 1886), p. 122. 
estas imágenes; salas enormes de castillos cuya desnudez revela una realidad más lúgubre que la romántica. Se descubre que las mujeres no lo pasaban tan bien como hacían pensar los autores de la generación anterior; jugar a los bolos con el loco del castillo podía ser la única salida «cuando no existe sociedad y la biblioteca contiene apenas unas cuantas vidas de santos, que las niñas se saben de memoria, y algunos tratados venatorios de una falta de interés indiscutible» ${ }^{62}$, palabras que parecen un eco del pensamiento de Lefèvre ${ }^{63}$.

Por más que algunos poetas románticos, de acuerdo con aquellos arqueólogos que todo lo encuentran precioso con tal que cuente siglos de antigüedad, hayan tratado de describirnos como muy agradable y entretenida la vida de la mujer poco menos que encarcelada en esos nidos de águila que se llaman, o se llamaban castillos feudales; ello es que, por lo que sabemos de positivo, las castellanas, debían aburrirse de lo lindo, por más linajudas o blasonadas que fuesen.

Hijas, esposas o hermanas de algún señor, cuya mejor distracción era talar las propiedades de un vecino empingorotado, por el simple gusto de andar a la greña con el ofendido; sin más distracción que las místicas lecturas del capellán o de tarde en tarde los rústicos versos de algún trovador algo menos simpático que el del drama de García Gutiérrez o de las novelas de Walter Scott, ¿qué habían de hacer esas pobres mujeres sino bordar bandas para los torneos o educar palomas, como la de nuestro cuadro ${ }^{64}$.

Se trata de un distanciamiento respecto a la demasiada estereotipación del segmento femenino medieval (con una preferente referencia al castellano) durante el Romanticismo. De la inocente doncella que disfruta de los galanteos de sus trovadores se pasa ahora a la mujer noble insastifecha en su gineceo, plena de aburrimiento por su escasa capacidad de acción, desencuadrada en un mundo medieval donde predomina la barbarie ${ }^{65}$.

62 «Nuestros grabados./ Una partida de bolos, cuadro por A. Viendt», La Ilustración Artística, 141 (8 de septiembre de 1884), p. 291. El texto empieza en la línea de lo que venimos señalando: «La vida en los castillos señoriales era, si mucho se apura, regalona y ostentosa, pero adolecía de monótona».

63 Según Dakyns (1973: 110-123), en los años 50 franceses la Edad Media fue pintada de manera muy negativa. André Lefèvre presentará a las damas medievales como dispuestas a entregarse al primer recién llegado, por ejemplo al cantor, pues se encontraban encerradas mientras el barón se divertía. En la Edad Media no había reuniones alegres ni salones ni libros ni conversación. Las cruzadas, los peregrinos buscando la hospitalidad en la tormenta y los trovadores alegrando las largas veladas de invierno con canciones fueron descritos en una luz muy diferente a la romántica por este francés. Aparece ya entonces la versión aburrida de la Edad Media.

64 «Nuestros grabados./ La castellana, cuadro de O. Probster», La Ilustración Artística, 87 (27 de agosto de 1883), pág. 275.

65 «Cuanto más dura es la vida, mayor necesidad de expansión siente el alma, y especialmente el alma de la mujer, criatura venida al mundo para amar y ser amada. La antigua castellana, prisionera, más que señora, en la mansión feudal de su esposo, ro- 
Esta preocupación por el tedio de la población femenina (presente también en obras de tema contemporáneo como La Regenta) se expresa además mediante la iconografía de su figura en la ventana: la mujer, medieval o contemporánea, mira a través del cristal hacia un espacio donde está lo nuevo y lo inexplorado (Bastida de la Calle, 1996: 311), tema que aparecerá también en los grabados ingleses (Reid, 1975: 15, 37 y 82). La dama que aguarda encerrada la vuelta de su caballero implica necesariamente una connotación de opresión, de encerramiento, un asunto que se dejará traslucir en las poesías sobre las Cruzadas. Se trata de la espera de la mujer pasiva a ese amor que promete volver, que luego será retomado por el movimiento simbolista (Dakyns, 1973), con fines distintos y mayor carga de idealización: dama y alma se identifican. También los prerrafaelistas abordarán el asunto, como nos muestran dos grabados de Rossetti, llenos de una melancólica complacencia ${ }^{66}$.

Vemos, pues, cómo en los comentarios a los grabados de las revistas ilustradas catalanas, encontramos esa preocupación por el aburrimiento de la mujer medieval, encerrada en un castillo o en el harén ${ }^{67}$, desde una postura a la vez realista y progresista y desde una voluntaria intención de desmitificación del Medievo. De este modo, pese a que no se abandone la visión de la mujer como esposa y madre, un discurso subyacente deja implícito que esta función no basta para hacer feliz a la mujer, pues, si no tiene mejor ocupación que vivir aislada en una fortaleza donde nada puede hacer, siente "un abandono, una indiferencia, un malestar del alma» ${ }^{68}$.

La sociedad de los siglos medios es calificada de manera negativa, pues produce un estado de frustración en la mujer, sobre todo (curiosamente y a diferencia de lo que decía Michelet) en la de clase noble: «La sociedad en que padecen de aburrimiento, en que mueren de nostalgia las madres y los hijos de más elevada alcurnia, es una sociedad fuera de su centro, condenada a morir, como el ser sometido a la influencia de la máquina pneumática» ${ }^{69}$.

deada de gentes rudas a quienes todo se les iba en hablar de guerras o de caza; si por acaso llegaba a sentir una pasión correspondida, debía arriesgarlo todo en un trance decisivo, imprudente y a menudo criminal». «Nuestros grabados./ La sorpresa», La Ilustración Artística, 210 (4 de enero de 1886), p. 3.

66 «The Prince's Progress (1866) likewise contains two designs - 'The long hours go and come and go' - a picture of a girl leaning from a window, waiting for her lover; and 'You should have wept her yesterday' - a picture of the Prince's arrival, too late» (Reid, 1975: 46).

${ }_{67}$ Léanse los comentarios a los grabados siguientes: «Nuestros grabados./ En el harem, cuadro de Juan B. Hunsmans», La Ilustración Artística, 222 (29 de marzo de 1886), p. 114; «Nuestros grabados./ Huyendo del fastidio», La Ilustración Artística, 234 (21 de junio de 1886), p. 218.

68 «Nuestros grabados./ Nostalgia, cuadro de G. Schuchinener», La Ilustración Artística, 240 (2 de agosto de 1886), p. 273.

69 «Nuestros grabados./ Nostalgia, cuadro de G. Schuchinener», La Ilustración Artística, 240 ( 2 de agosto de 1886), p. 273. Las palabras que preceden a este comentario 
Por otro lado, en la imaginería libresca, surgen también con el Realismo una serie de dibujantes que persiguen la faceta más realista de las escenas presentadas. En los dibujos de Pellicer, insertos sin marco en el texto ${ }^{70}$ en la cuidada edición de Montaner y Simón de La leyenda del Cid de Zorrilla (1882), de línea fina, sencillos, y sin grandes adornos - su sobriedad y desnudez se encuentra en armonía con el ambiente castellano que retrata-, percibimos esa sensualidad naturalista en la representación de las hijas del Cid desnudas (ibidem: 519). Hay aquí más interiores que en los grabados románticos, y la mirada del dibujante se dirige con simplicidad hacia el matrimonio que dialoga en una estancia o hacia la tan interesante iconografía de la mujer en soledad (Jimena piensa o escribe sola en su cuarto [ibidem: $187 ; 155]$ ). La mirada hacia lo doméstico conduce, paradójicamente, a un mayor protagonismo de la mujer en sustitución de las escenas de guerra, aunque sea para figurar cerca de la chimenea del hogar hablando con su criada (ibidem: 19).

En resumidas cuentas, el desarrollo de la Psicología permitirá un acercamiento más profundo a los personajes del Medievo. Recordemos que en el Romanticismo ese intento de recuperación del pasado iba acompañado de calificativos que consideraban a la Reconquista siempre de un modo excepcional, único, sobrehumano, épico; pero en la segunda mitad de siglo se replantea el sinsentido de volver a una época que disponía de unos héroes irrecuperables e inalcanzables ${ }^{71}$. La labor realista fue aproximar un poco más estos hombres a los decimonónicos; indirectamente, el positivismo ayudó en esta tarea, con toda la revisión historiográfica que se realiza a

son las siguientes: «Cuanto más se profundiza en el estudio de las costumbres de la Edad Media, mayor convencimiento se adquiere de la triste suerte que cabía a la mujer, aun cuando su buena estrella la hubiese deparado una cuna dorada en la más suntuosa cámara de un viejo castillo. La dureza de la vida podía tener sus encantos para aquellos hombres de hierro que, a falta de mejor distracción, se batían encarnizadamente en campo abierto o cerrado, uno contra uno, o ciento contra ciento... Pero la mujer, la mujer nacida para amar y ser amada, la mujer cuya delicadeza física es comparable solamente con la delicadeza de sus sentimientos de esposa y madre, ¿qué papel representaba en el interior de un cuartel llamado castillo, unida a un varón o barón que, cuando no tenía fortalezas que asaltar, asaltaba caminantes, y madre de un hijo a quien se educaba para que en todo se pareciese a su padre?.../ La consecuencia natural de esas costumbres había de ser forzosamente la nostalgia de la mujer y del niño; de suerte, que el autor del cuadro (...) ha sintetizado una época, y (...) ha hecho la más severa crítica del feudalismo».

70 Los románticos intentarán en sus libros esa integración total de lo visual y lo verbal que atribuían a los copistas medievales. Ésta se consigue con una nueva modalidad de xilografía, que integra la imagen en el texto (Rosen y Zerner, 1988: 81). También Apeles Mestres presenta así sus dibujos, insertos en medio de la página, sin transiciones ni fondo, en las Obras completas del Duque de Rivas (Saavedra, 1884-1885).

71 Contra la idealización del pasado se manifiestan Pardo Bazán o Núñez de Arce. Después del 98 sabemos que la protesta se hará mayor. Se ataca entonces el último reducto paradisíaco, bajo la influencia de variados motivos ideológicos. 
partir de sus premisas: la historia de la segunda mitad del XIX reconoce que muchas de las batallas medievales se produjeron más por ambiciones personales que por motivos religiosos, y que las mujeres padecían otra suerte de marginación. $\mathrm{Y}$ esto es importante porque, siendo como era el Medievo una época «sagrada», era desacostumbrado contemplarlo de un modo algo menos mitificador.

El distanciamiento del movimiento realista lo heredará el Modernismo, aunque desde una postura muy distinta. De hecho, con esta corriente volverá una voluntaria mitificación del segmento femenino medieval, descendiente de la doble consideración de la mujer en el Medievo, ya sea a partir de unos tintes fatalistas: la mujer identificada con el Demonio y la carne, o desde la figura prerrafaelista de Beatriz, que hace ya su aparición en la década de los $80^{72}$, y que también encontraremos en relatos de Pardo Bazán ${ }^{73}$.

\section{BIBLIOGRAFÍA CITADA ${ }^{74}$}

ACUÑA, Rosario de (1990), Rienzi el Tribuno. El padre Juan. Teatro, edición, introducción y notas de María del Carmen Simón Palmer, Madrid, Editorial Castalia/ Instituto de la Mujer.

BASTIDA DE LA CALLE, M. ${ }^{a}$ Dolores (1996), «La mujer en la ventana: Una iconografía del XIX en pintura e ilustración», Espacio, Tiempo y Forma, VII, 9, pp. 297-315.

BENÍTEZ, Rubén (1971), Bécquer tradicionalista, Madrid: Gredos.

BLASCO IBÁÑ̃E, Vicente (1987), Obras completas con una nota biobibliográfica. Tomo $I V$, Madrid: Aguilar.

BLOCH, R. Howard, y Stephen G. NiCHOLS (1996), «Introduction», en Bloch y Nichols, eds., Medievalism and the Modernist Temper, Baltimore and London: The John Hopkins University Press, pp. 1-22.

Boos, Florence S., ed. (1992), History and Community. Essays in Victorian Medievalism, Nueva York/ Londres: Garland Publishing, Inc.

BRETZ, Mary Lee (1992), Voices, Silences and Echoes. A Theory of the Essay and the Critical Reception of Naturalism in Spain, London: Tamesis.

BuRNS, E. Jane, Kay, Sarah, Krueger, Roberta L., y Solterer, Helen (1996), «Feminism and the Discipline of Old French Studies: Une Bele Disjointure», en Bloch y Nichols, eds., Medievalism and the Modernist Temper, Baltimore and London: The John Hopkins University Press, pp. 225-266.

CABrales ARTEaGa, José Manuel (1984), La Edad Media en el teatro español, entre 1875 y 1936. [Tesis doctoral de la Facultad de Filología de la Universidad Complutense de Madrid, 1984, 6 vls.].

72 Véase, por ejemplo, F. VERA Y GONZÁLEZ, «Amado por su persona», La Ilustración de España, 18 (8 de mayo de 1886), p. 139. Carlos RuBIo, «La Calumnia», La Ilustración de España, 2 (8 de enero de 1886), pp. 14-15.

73 Véase Pardo Bazán (1990, I: 96-102; 157-161).

74 En este artículo, he utilizado el sistema de citación americano, exceptuando los textos o grabados provenientes de la prensa ilustrada, que se señalan a pie de página. 
CASTElar, Emilio (1879), Fra Filippo Lippi, Barcelona: Emilio Oliver y Compañía, Editores, segunda edición, 3 ts.

- (1885-1886), El suspiro del moro. Leyendas, tradiciones, historias referentes a la conquista de Granada, Madrid: Imprenta de Fortanet, 2 ts.

COHRAM, Rebeca (1992), «Tennyson's Hierarchy of Women in Idylls of the King», en Florence S. Boos, ed., History and Community. Essays in Victorian Medievalism, Nueva York/ Londres: Garland Publishing, Inc., pp. 81-107.

Coloma, P. Luis, S. J. (1952), Obras completas, tercera edición, Madrid/ Bilbao: Editorial «Razón y fe»/ Editorial «El mensajero del C. de J.».

DAKYNS, Janine R. (1973), The Middle Ages in French Literature. 1851-1900, Londres: Oxford University Press.

DE GIROlami CheneY, Liana (1992), «The Fair Lady and The Virgin in Pre-Raphaelite Art: The Evolution of a Societal Myth», en Pre-Raphaelitism and Medievalism in the Arts, ed. Liana de Girolami Cheney, Lewiston/ Queenston/ Lampeter: The Edwin Mellen Press, pp. 241-279.

FERNÁNDEZ Y GONZÁLEZ, Manuel (1958), Los siete Infantes de Lara. (Novela histórica tradicional), Madrid: Colección Popular Literaria.

FERRARI, Emilio (1910), Obras completas. Tomo II: Poemas, Madrid, Imp. de la Revista de Archivos.

FERRER DEL Río, Antonio (1851), Examen histórico-crítico del reinado de Don Pedro de Castilla. Obra premiada por voto unánime de la Real Academia Española en el certamen que abrió la misma en 2 de Marzo de 1850, Madrid: Imprenta Nacional.

FUERY, Patrick, y Nick MANSFIELD (1997), Cultural Studies and the New Humanities. Concepts and Controversies, Melbourne: Oxford University Press.

GARCÍA GuTIÉRREZ, Antonio (1866), Obras escogidas por Don Antonio García Gutiérrez, edición hecha en obsequio del autor, Madrid: Imprenta y Esteriotipia de M. Rivadeneyra.

Gichot, Joaquín (1878), Don Pedro Primero de Castilla. Ensayo de vindicación crítico-histórica de su Reinado, Sevilla: Imp. de Gironés y Orduña.

GIES, David Thatcher (1994) The Theatre in Nineteenth Century Spain, Cambridge: Cambridge University Press.

GirouARD, Michael (1981), The Return to Camelot. Chivalry and the English Gentleman, New Haven and London: Yale University Press.

HENN, David (1999), «Reflections of the War of 1898 in Pardo Bazán's Fiction and Travel Chronicles», The Modern Language Review, 94, 2, pp. 415-425.

JiMÉNEZ MORALES, María Isabel (1997), Escritoras malagueñas del siglo XIX, Málaga: Universidad de Málaga.

LiTVAK, Lily (1979), Erotismo fin de siglo, Barcelona: Antonio Bosch, editor.

- (1985), El jardín de Aláh. Temas del exotismo musulmán en España. 1880-1913, Granada: Editorial Don Quijote.

MADRAZO, Pedro de (1858), «Prólogo», en Francisco Javier SIMONET, Leyendas históricas árabes, Madrid: J. J. Martínez, editor, pp. i-xv.

MANZANARES DE CIRRE, Manuela (1971), Arabistas españoles del siglo XIX, Madrid: Instituto Hispano Árabe de Cultura.

MENÉNDEZ PELAYo, Marcelino (1944), Antología de poetas líricos catellanos, edición preparada por Enrique Sánchez Reyes, t. I, Santander: Aldus. (Edición nacional de las obras completas de Menéndez y Pelayo, dirigida por Miguel Artigas, t. XVII, Madrid: CSIC).

Michelet, Jules (1966), La Sorcière, cronología y prefacio de Paul Viallaneix, París: Garnier-Flammarion. 
MiLIARAS, Barbara (1992), «Womanly Noblesse: The Influence of the Courtly Love Tradition on Edward Burne-Jones», en Pre-Raphaelitism and Medievalism in the Arts, ed. Liana de Girolami Cheney, Lewiston/ Queenston/ Lampeter: The Edwin Mellen Press, pp. 193-219.

PARDo BAZÁn, Emilia (1882), San Francisco de Asís (siglo XIII). Tomos I y II, Madrid: Librería de D. Miguel Olamendi.

- (1990), Cuentos completos, estudio preliminar, edición, bibliografía, notas y censo de personajes de Juan Paredes Núñez, La Coruña: Fundación «Pedro Barrie de la Maza conde de Fenosa», ts. I-IV.

PÉREZ GALDós, Benito (1974), «Quien mal hace, bien espere. Ensayo dramático en un acto y en verso», ed. Ricardo Doménech, en Estudios Escénicos, 18 (septiembre), pp. 253-292. (Cuadernos del Instituto de Teatro. Número especial dedicado a Benito Pérez Galdós)

PeSeT, J. L., S. GARMA y J. S. PÉrez GARZón (1978), Ciencias y enseñanza en la revolución burguesa, Madrid: Siglo Veintiuno de España, Editores.

REID, Forrest (1975), Illustrators of the Eighteen Sixties. An illustrated Survey of the Work of 58 British Artists, Nueva York: Dover Publications.

RinCón GaRCÍA, Wifredo (1987), Francisco Pradilla. 1848-1921, Madrid: Antiquaria.

SÁNCHEZ LlAMA, Íñigo (1999), «María del Pilar Sinués de Marco y la cultura oficial peninsular del siglo XIX: del neocatolicismo a la estética realista», Revista Canadiense de Estudios Hispánicos, XXIII, 2, pp. 271-288.

SERRANO DE HARO, Amparo (2000), Mujeres en el arte. Espejo y realidad, prólogo de José Jiménez, Madrid: Plaza \& Janés Editores.

VALERA, Juan (1905-1913), Obras completas, Madrid: Imprenta alemana.

- (1905), OC. Tomos I y II: Discursos académicos.

- (1907), OC. Tomo XIV. Cuentos: Parsondes. El pájaro verde. El bermejino prehistórico. El espejo. El pescadorcito Urashima. El hechicero. La muñequita. La Buena Fama.

- (1908), OC. Tomo XV. Cuentos: El caballero del Azor. El doble sacrificio. Los cordobeses en Creta. El duende-beso. El último pecado. El San Vicente Ferrer, de talla. El cautivo de Doña Mencía. El maestro Raimundico. Garuda o la cigüeña blanca. Cuentos y chascarrillos andaluces.

- (1910), OC. Tomo XXIV. Crítica literaria (1873-1878).

- (1913). OC. Tomo XXXIV. Estudios críticos sobre filosofía y religión (1856-1863).

WATERS, Chris (1992), «Marxism, Medievalism and Popular Culture», en Florence S. Boos, History and Community. Essays in Victorian Medievalism, Nueva York/ Londres: Garland Publishing, Inc., pp. 137-168.

ZORRILla, José (1852), Granada, poema oriental, precedido de la Leyenda de Al-Hamar, París: Imprenta de Pillet Fils Ainé, 2 ts.

- (1859), Cantos del trovador. Colección de leyendas y tradiciones históricas, Madrid/ Barcelona: Librería de San Martín/ En el Plus Ultra.

- (1882), La leyenda del Cid, escrita en verso por don José Zorrilla e ilustrada por D. J. Luis Pellicer, Barcelona: Montaner y Simón, Editores.

- (1894), Ecos de las montañas, ilustradas por Gustavo Doré, Barcelona: Montaner y Simón, Editores. 